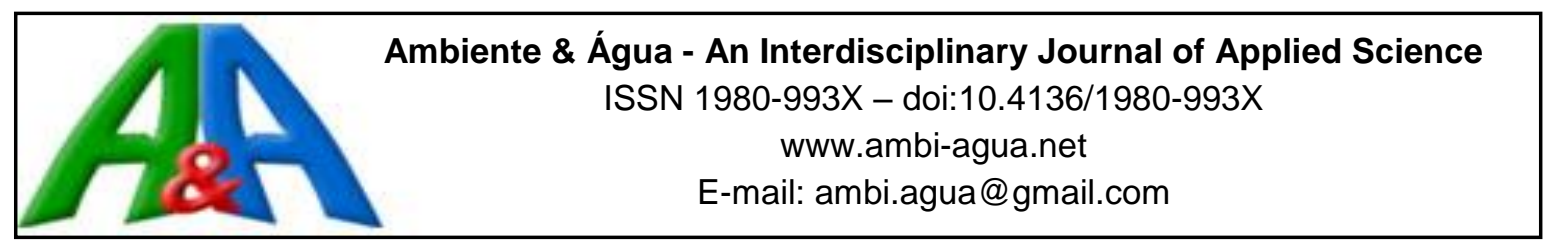

\title{
Hydrological modeling of an experimental basin in the semiarid region of the Brazilian State of Pernambuco
}

\author{
ARTICLES doi:10.4136/ambi-agua.2204
}

Received: 26 Oct. 2017; Accepted: 23 Sep. 2018

\author{
Adriana Guedes Magalhães ${ }^{1 *}$; Abelardo Antônio de Assunção Montenegro" ${ }^{1}$; \\ Carolyne Wanessa Lins de Andrade²; Suzana Maria Gico Lima Montenegro ${ }^{3}$; \\ Robertson Valério de Paiva Fontes Júnior ${ }^{1}$ \\ ${ }^{1}$ Universidade Federal Rural de Pernambuco (UFRPE), Recife, PE, Brasil \\ Departamento de Engenharia Agrícola (DEAGRI).E-mail: agmguedes@gmail.com, \\ abelardo.montenegro@yahoo.com.br,rr_fontes@hotmail.com \\ ${ }^{2}$ Universidade Federal Rural de Pernambuco (UFRPE), Recife, PE, Brasil \\ Unidade Acadêmica de Serra Talhada (UAST). E-mail: carolynelins200@gmail.com \\ ${ }^{3}$ Universidade Federal de Pernambuco (UFPE), Recife, PE, Brasil \\ Departamento de Engenharia Civil (DECIVIL).E-mail: suzanam.ufpe@gmail.com \\ *Corresponding author
}

\begin{abstract}
Hydrological simulation models have proven to be an important tool for managing and planning water resources, enabling the assessment of the impacts of rainfall on surface runoff and soil moisture. This work therefore aimed to apply the SWAT model for the analysis of hydrological processes in the Experimental Basin of the Jatobá Stream, in the semiarid region of the State of Pernambuco, Brazil, considering the calibration and validation of the model from streamflow and soil moisture data. Moreover, the study investigated hydrological effectiveness in a recovery scenario in areas of higher topographic elevation of the arborescent Caatinga and the behavior of the hydrological components under an agricultural expansion scenario. Events which occured between 2009 and 2010 were used to calibrate and validate streamflow and soil moisture data. The calibration and validation of streamflow exhibited efficiency coefficients (NSE) of 0.58 and 0.42 , respectively, and 0.53 and 0.46 for soil moisture. The adjustment of the parameters was considered adequate for representing streamflow recession periods. It was also verified that the alternative process of calibration and validation with soil moisture reduced uncertainty. Regeneration of the vegetative cover over $21 \%$ of the hilltop areas of arborescent Caatinga led to a significant increase in percolation (42\%) and a decrease of $34 \%$ in soil moisture (due to water consumption by plants), thus contributing to the recovery of headwaters, increasing resilience to water scarcity. On the other hand, the $38 \%$ expansion of agriculture caused an increase of $11 \%$ in surface runoff and, consequently, an increase of $10 \%$ in soil moisture.
\end{abstract}

Keywords: Caatinga, hydrological models, multiple datasets, SWAT model. 


\section{Modelagem hidrológica em bacia experimental do semiárido Pernambucano}

\section{RESUMO}

A simulação de processos hidrológicos apresenta-se como importante ferramenta de gestão e planejamento dos recursos hídricos, possibilitando avaliação dos impactos da precipitação sobre a geração de escoamento superficial e umedecimento do solo. O objetivo do presente trabalho foi aplicar o modelo hidrológico SWAT para análise de processos hidrológicos na Bacia Experimental do Riacho Jatobá, no semiárido de Pernambuco, considerando a calibração e a validação do modelo a partir de dados de vazão e de umidade do solo. Além disso, o estudo buscou investigar a efetividade hidrológica em um cenário de recomposição de Caatinga arbórea em áreas de maior elevação topográfica na bacia experimental, e o comportamento dos componentes hidrológicos em um cenário de expansão agrícola. Para a calibração e validação da vazão e umidade do solo utilizaram-se eventos ocorridos entre 2009 e 2010 . A calibração e a validação com a vazão apresentaram coeficientes de eficiência NSE de 0,58 e 0,42, respectivamente, e para a umidade do solo de 0,53 e 0,46, respectivamente. Os ajustes dos parâmetros foram adequados para representar os períodos de recessão do escoamento. Verificou-se que o processo alternativo de calibração e validação por meio da umidade do solo possibilitou a redução nas incertezas. Cenários de recomposição da cobertura vegetal de $21 \%$ na área de Caatinga arbórea nos topos de morro produziram significativo aumento de $42 \%$ na percolação e diminuição de $34 \%$ na umidade do solo (devido ao consumo de água pelas plantas), contribuindo assim para a recuperação das nascentes e aumentando a resiliência frente a cenários de escassez hídrica. Por outro lado, o cenário de expansão agrícola de $38 \%$, provocou aumento de $11 \%$ no escoamento superficial e, consequentemente, um aumento de $10 \%$ na umidade do solo.

Palavras-chave: Caatinga, modelos hidrológicos, múltiplos conjuntos de dados, modelo SWAT.

\section{INTRODUCTION}

The Caatinga, a typical vegetation of the Brazilian semiarid region, is comprised of woody, herbaceous, cactaceous and bromeliaceous species that exhibit under the adverse climatic and hydrological conditions of the region. In the semiarid region, the Caatinga vegetation is subjected to an intense process of degradation, due to deforestation and the burning of natural vegetation to allow for the planting of cash crops and pastures. According to Blainski et al. (2017), changes in plant cover without planning and without proper management of natural resources can have negative effects on the ecosystem and water availability. The substitution or removal of natural vegetation affects hydrological processes and budgets, causing lower water retention during droughts and increasing overland flow during rainy seasons. The increase in surface runoff may present problems such as soil nutrient losses and the production of sediment, leading to the sedimentation of reservoirs and rivers. Bales (2015), Ilstedt et al. (2016) and Şen (2015) verified that the positive water vegetation nexus is indirect, as increases in vegetative cover, although producing higher evapotranspiration, may at the same time increase infiltration, and therefore possibly enlarge subsurface water storage, particularly at the vadose zone. Such a hypothesis, however, requires proper analysis, as it depends on multiple variables, changing across scales.

Several studies have used hydrological models, such as the Soil and Water Assessment Tool (SWAT), to evaluate the hydrological impact of changes in vegetation cover in watersheds. The SWAT model combines climatic, topographic, edaphic, and land use factors 
to evaluate the variation of the hydrological conditions of the watersheds, identifying the vulnerabilities related to water quantity and quality in the basin. According to Britto et al. (2014), the results from the combination of these factors can be applied effectively in the development of watersheds management plans.

The SWAT model has been listed as a keyword in $12 \%$ of published international articles from 2009 to 2013 (Li et al., 2014). In Brazil, between 1999 and 2015, the model was used in more than 100 studies published in Brazilian and international journals (Bressiani et al., 2015). The applications of the SWAT model include studies of the streamflow calculation (Brighenti et al., 2016; Melo Neto et al., 2014; Aragão et al., 2013; Andrade et al., 2013), transport of sediments and pollutants (Silva and Medeiros, 2014; Veiga, 2014; Galharte et al., 2014), and in the quantification of impacts resulting from changes in land use on hydrological and sedimentological dynamics (Aragão et al., 2013; Blainski et al., 2011; Rodrigues et al., 2015; Silva et al., 2015; 2018). Santos (2015) analyzed sediment production and its spatial distribution with the SWAT model in the Tapacurá River Basin $\left(472 \mathrm{~km}^{2}\right)$, State of Pernambuco. Brighenti et al. (2016) verified that the SWAT model was representative in the simulations of streamflow data in wet and dry periods in the Negrinho River Basin $\left(200 \mathrm{~km}^{2}\right)$ in Santa Catarina. Silva and Medeiros (2014) analyzed the spatial and temporal variability of surface runoff and sediment production using the SWAT model in the São João do Cariri Experimental Basin (BESJC), with an area of $13.5 \mathrm{~km}^{2}$. The results presented adequate efficiency in the analysis of sediment yield and streamflow, with Pearson's Linear Correlation Coefficients of 0.84 and 0.88, and Nash-Sutcliffe Coefficients of 0.03 and 0.77, respectively.

Finger et al. (2015) pointed out that calibration and validation with multiple data sets increases the overall performance of hydrological models. Applying SWAT to a semiarid catchment in Australia, Kundu et al. (2017) endorsed the value of remotely sensed surface soil moisture in conjunction with flow data for improving model calibration using SWAT, despite the low correlation between satellite outputs and in situ observations. Previously, adopting the Dicasm model for the Alto Ipanema catchment (which encompasses the Jatobá Basin adopted in this study), Montenegro and Ragab (2010) analyzed the impact of land-use changes on water availability, using jointly flow and in situ soil moisture data, and verified the relevance of multiple data sets to achieve a more rigorous model simulation.

The Jatobá River Experimental Basin (BERJ) is located in the semiarid region of Pernambuco, where rainfall is extremely irregular and water courses are intermittent. Due to its characteristics, the Network of Hydrology of the Semiarid Region (REHISA) has been monitoring and conducting different studies around the basin area. The years 2009 and 2010 presented high precipitation in the region, with flow generation in the Alto Ipanema Basin (Silva Junior et al., 2011), in which the BERJ is inserted. In the last six years, the Alto Ipanema Basin (a tributary of the São Francisco River) had very little rainfall, which significantly reduced surface runoff generation.

Several studies have been carried out with reference to soil moisture in the BERJ (Santos et al., 2011; Silva et al., 2015; Silva Junior et al., 2016), addressing the performance of soil conservation techniques. At plot scale, Silva et al. (2015) simulated soil water dynamics in the BERJ. In the Alto Ipanema Basin, Montenegro and Ragab (2010) studied temporal variations of runoff and soil moisture in the basin, considering different scenarios of land use in climate. However, it should be noted that there is still a lack of studies addressing soil moisture dynamics under different land-use scenarios in the Brazilian semiarid basins, particularly at an experimental catchment scale.

Thus, the use of the SWAT model under land-use changes, together with the climatic diversity of biomes and water availability of the semiarid region of the Brazilian Northeast, provide relevant information for future studies that address the impact of vegetal cover changes on the water resources in similar watersheds. 
This work therefore aims to apply the SWAT model for the analysis of hydrological processes in the Experimental Basin of the Jatobá Stream, in the semiarid region of State of Pernambuco, Brazil, considering the joint calibration and validation for both in situ streamflow and soil moisture data. Moreover, the study investigates the hydrological effectiveness in a reforestation scenario of the arborescent Caatinga in areas of higher topographic elevation, and the behavior of the hydrological components under an agricultural expansion scenario.

\section{MATERIAL AND METHODS}

\subsection{Study Domain}

The Experimental Basin of the Jatobá Stream (BERJ) is $13.50 \mathrm{~km}^{2}$, with a perimeter of 16 $\mathrm{km}$, located between the coordinates of $8^{\circ} 34^{\prime} 17^{\prime \prime}$ and $8^{\circ} 18^{\prime} 11^{\prime \prime}$ South Latitude and $37^{\circ} 1^{\prime} 35^{\prime \prime}$ and $36^{\circ} 47^{\prime} 20^{\prime \prime}$ West Longitude (Melo and Montenegro, 2015). The basin is located in the municipality of Pesqueira and is inserted in the Representative Basin of the Alto Ipanema River, in the semiarid region of Pernambuco, and represents one of the sub-basins investigated by the Network of Hydrology of the Semiarid Region (REHISA).

The Alto Ipanema River Basin is a sub-basin in the upstream part of the Ipanema River, an affluent of the Low São Francisco River Basin (Figure 1). The prevailing climate in the region is characterized as extremely hot semiarid steppe Type, according to the Köppen classification, with a mean annual rainfall of $600 \mathrm{~mm}$ and an average temperature of $23{ }^{\circ} \mathrm{C}$, and potential evapotranspiration of approximately 2,000 $\mathrm{mm}$ a year (Melo and Montenegro, 2015). Furthermore, the vegetation is predominantly hyperxerophytic Caatinga (Montenegro and Montenegro, 2006).

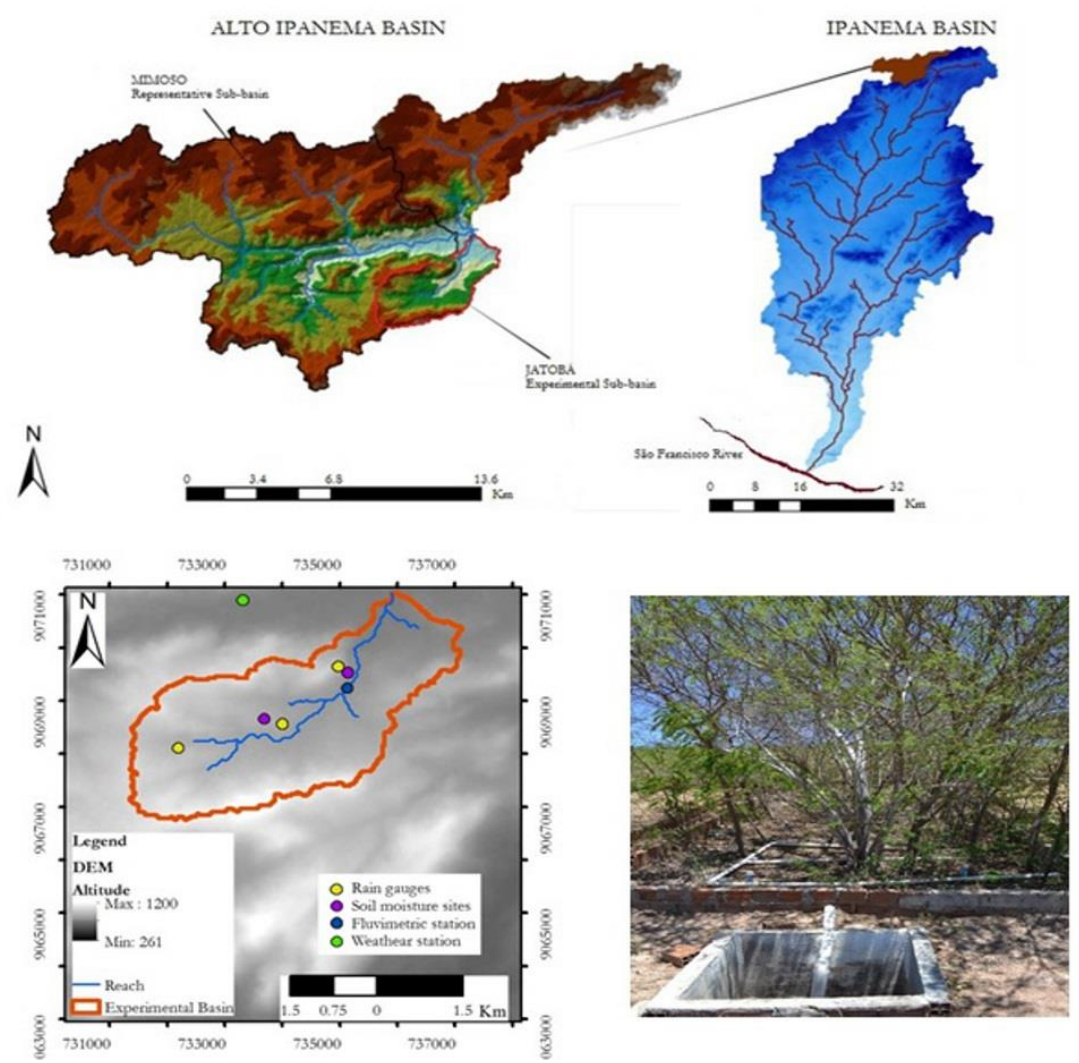

Figure 1. Location of the Jatobá Stream Experimental Basin, Alto Ipanema River Basin, inserted in the Ipanema Basin in Pesqueira $\mathrm{PE}$, digital elevation model, location of rain gauges, weather station, and fluviometric station, and soil moisture measurement sites. 


\subsection{SWAT Model}

SWAT is a hydro-sedimentological model which simulates different hydrological processes, estimating streamflow, sediment movement and nutrient cycling. The model requires specific data of climate, temperature, soil properties, topography and vegetation. The model is based on the water balance equation (Equation 1) in order to simulate the hydrologic cycle as well as to estimate surface runoff using the Curve Number method (CN) (Equation 2) (Neitsch et al., 2005).

$$
\mathrm{SW}_{\mathrm{t}}=\mathrm{SW}_{0}+\sum_{\mathrm{i}=1}^{\mathrm{t}}\left(\mathrm{R}_{\text {day }}-\mathrm{Q}_{\text {surf }}-\mathrm{E}_{\mathrm{a}}-\mathrm{w}_{\text {seep }}-\mathrm{Q}_{\mathrm{gw}}\right)
$$

Where: $S w_{t}$ is the final water content $(\mathrm{mm}) ; S W_{0}$ is the initial water content $(\mathrm{mm}) ; t$ is the time (days); $R_{\text {day }}$ is the amount of precipitation on day $i(\mathrm{~mm}) ; Q_{\text {surf }}$ is the amount of surface runoff on day $i(\mathrm{~mm}) ; \mathrm{E}_{\mathrm{a}}$ is the amount of evapotranspiration on day $i(\mathrm{~mm}) ; w_{\text {seep }}$ is the amount of percolation on day $i(\mathrm{~mm})$, and $Q_{g w}$ is the amount of bypass exiting the soil profile bottom on day $i(\mathrm{~mm})$.

$$
Q_{\text {surf }}=\frac{\left(\mathrm{R}_{\text {day }}-\mathrm{I}_{\mathrm{a}}\right)^{2}}{\left(\mathrm{R}_{\text {day }}-\mathrm{I}_{\mathrm{a}}+S\right)}
$$

Where: $I_{a}$ is the initial abstractions which includes surface storage, interception and infiltration prior to runoff $(\mathrm{mm})$, and $S$ is the retention parameter $(\mathrm{mm})$.

For hydrological modelling using SWAT, the river basin was divided into sub-basins, each being divided into hydrologic response units (HRUs), characterized by the combinations of land use and management, soil types and slope (Aragão et al., 2013).

\subsection{Inputs and Instrumentation}

The delimitation of the sub-basins of the Experimental Basin of the Jatobá Stream was carried out using the ArcSWAT extension based on the image from the Shuttle Radar Topography Mission (SRTM), with a spatial resolution of $30 \mathrm{~m}$, obtained from the website of the Brazilian Institute of Space Research (INPE) (Figure 1). Meteorological information such as maximum and minimum temperature $\left({ }^{\circ} \mathrm{C}\right)$, solar radiation $\left(\mathrm{MJ} \mathrm{m}^{-2}\right)$, relative humidity $(\%)$ and wind speed $\left(\mathrm{m} \mathrm{s}^{-1}\right)$ were registered at an automatic agrometeorological station (Model GRWS100 - Campbell Scientific $($ ), inserted in the Alto Ipanema River Basin. The precipitation data used in the study were obtained from three automatic rain gauges located in the Experimental Basin. For measuring soil moisture, experimental sites of $198 \mathrm{~m}^{2}$ were used with four different soil covers, one with natural Caatinga Vegetation, two plots with general agriculture and one with bare soil, with effective dimensions of $4.5 \mathrm{~m} \mathrm{x} 11 \mathrm{~m}$, in a total area of $49.5 \mathrm{~m}^{2}$ each (Figure 1). Five Time Domain Reflectometry (TDR) sensors were installed at soil depths of $20 \mathrm{~cm}$ at each layer, with hourly measurements. These measurements of soil moisture were extrapolated for the sub-basin in which the layer is inserted.

The period defined for the study of the hydrological behavior of the sub-basins ranged from 2009 to 2010, with simulations from rain gauge measurements and moisture measurement sites.

The land-use map was drawn based on images from the RapidEye satellite from April 2013, from the REHIDRO project (Lima et al., 2014). Land use was divided into six different classifications (Figure 2A): Agriculture, Gallery Forest, arborescent closed Caatinga, arborescent-shrubby closed Caatinga, arborescent-open Caatinga and Bams (Silva Junior et al., 2011). The soil-types map was based on soil mapping carried out by EMBRAPA-Soils, from information provided by the Agroecological Zoning of Pernambuco (ZAPE) (EMBRAPA, 2000), identifying three predominant soil types: red-yellow Clay soil, Litolic Neosoil and Regolitic Neosoil (Figure 2D).

\section{IPABH}




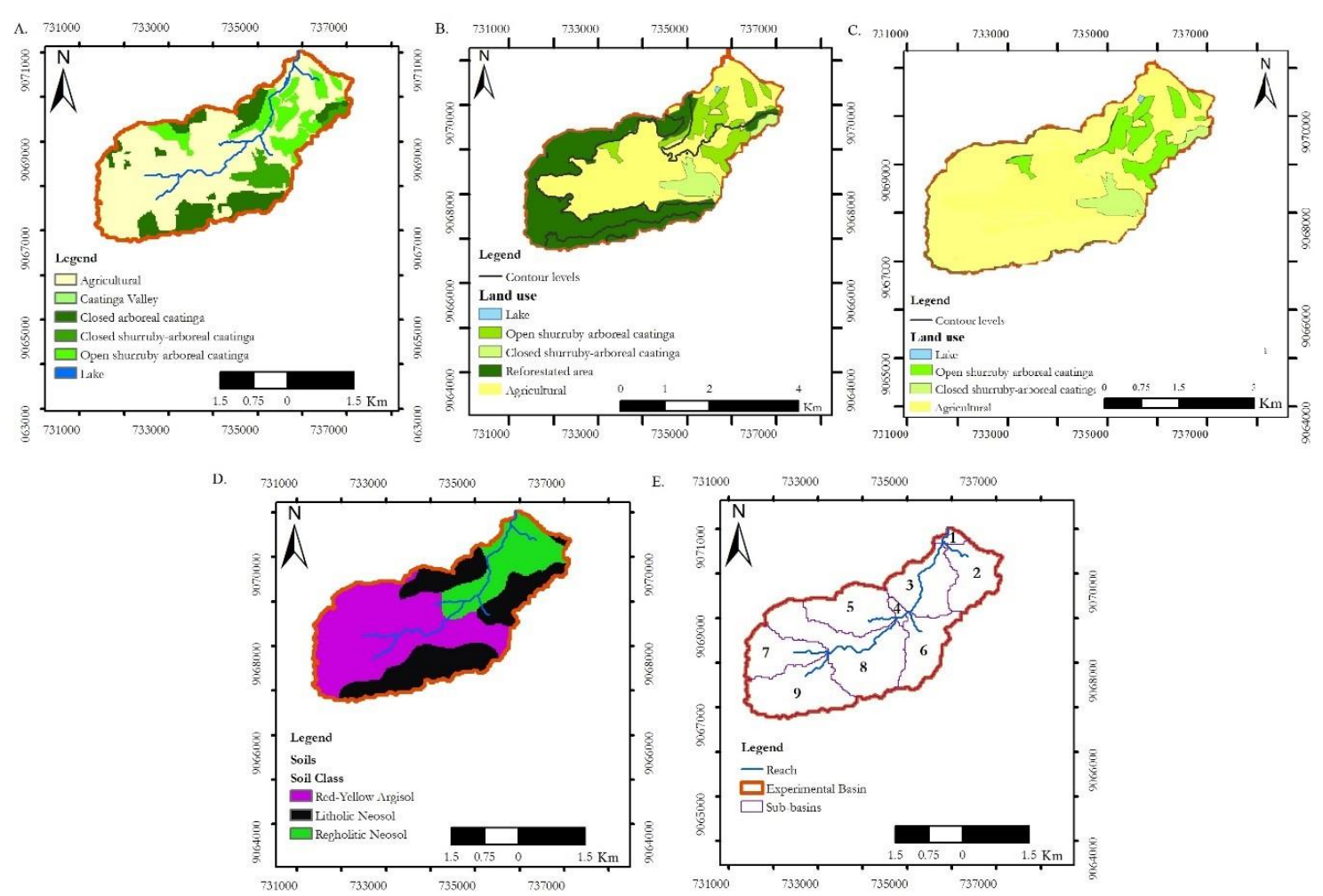

Figure 2. Current land use map (A), Scenario 1: Reforestation Soil map (B), Scenario 2: Agricultural expansion map (C), soil map (D) and delineating of sub-basin in SWAT model for the Jatobá Stream Basin, Pesqueira-PE (E).

In order to improve the performance of the SWAT model, before initiating the calibration and validation processes, some parameters were modified in relation to the default values of the model; such modifications are presented in Table 1. The modified values were based on previously published works that involved the Caatinga vegetation, for example the work developed by Silva (2014).

Table 1. Adjustment of key parameters for the BERJ in the SWAT model before beginning the calibration and validation procedures.

\begin{tabular}{|c|c|c|c|c|}
\hline $\mathrm{N}^{\mathrm{o}}$ & Parameter & Description & Default value & Adjusted value \\
\hline 1 & LAI_INIT & Initial leaf area index (range from 0 to 8 ) & 0 & 2 \\
\hline 2 & BIO_INIT & $\begin{array}{l}\text { Initial dry weight biomass }\left(\mathrm{kg} \mathrm{ha}^{-1}\right) \\
\text { (range from } 0 \text { to } 1000)\end{array}$ & 0 & 1000 \\
\hline 3 & PHU_PLT & $\begin{array}{l}\text { Total number of heat units or growing } \\
\text { degree days needed to bring plant to } \\
\text { maturity (range from } 0 \text { to } 3500 \text { ) }\end{array}$ & 0 & 2500 \\
\hline 4 & ESCO.hru and. bsn & $\begin{array}{l}\text { Soil evaporation compensation factor } \\
\text { (range from } 0 \text { to } 1 \text { ) }\end{array}$ & 0.95 & 0.6 \\
\hline
\end{tabular}

The SWAT model offers three options for estimating the potential evapotranspiration (ET0) component: the Penman-Monteith-FAO, Hargreaves \& Samani and Priestley-Taylor methods. The standard method of the model is the Penman-Monteith-FAO, which requires meteorological variables such as solar radiation, temperature, relative humidity and wind speed to estimate ET0 (Neitsch et al., 2005). In the present work, the Hargreaves \& Samani method was used, as it requires a smaller amount of data (only radiation and temperature), and because it fits very well in semiarid regions, as already verified for the Jatobá Basin. 


\subsection{Calibration and Validation}

Evaluation of the most sensitive parameters is considered a crucial step, which precedes the calibration and validation process of the given model (Arnold et al., 2012). The sensitivity analysis of the parameters was performed previously by Fontes Júnior (2016) using SWATCUP software, an independent software developed for uncertainty and sensitivity analysis, calibration and validation processes, using SWAT simulations (Abbaspour et al., 2007). The method used in SWATCUP was SUFI-2 (Sequential Uncertainty Fitting). This method is based on a Bayesian structure and determines uncertainties by sequential adjustment. Some studies report that the SUFI-2 method is an adequate technique for analyzing the uncertainty of modeling results (Khoi and Thom, 2015; Uniyal et al., 2015).

The sensitivity study was based on the analysis of parameters and input variables of the model, to observe those that, when altered, exert a significant influence on the results. We selected 19 parameters related to the processes of flow, evapotranspiration, percolation, recharge, infiltration, among others, for a first analysis. The parameters sensitivity was determined through the application of a multiple regression system, in which the parameters generated by the Latin Hypercubic Sampling are related to the objective function values. The t-test was used to identify the relative significance of each parameter, and the higher the value (in absolute terms) the parameter has, the more sensitive it will be. The p-value determines the significance of the sensitivity, and values close to zero indicate the most significant parameters (Abbaspour et al., 2015).

The model calibration was carried out manually using the ArcSWAT, using the manual calibration helper function. For the analysis of streamflow data, daily events were used, measured at the flow control cross-section, with a Soilinst ${ }^{\circledR}$ pressure transducer. For the calibration, events that had occurred in the period from 6/11/2009 to 8/27/2009 were used, with the period from 4/1/2010 to 5/31/2010 being adopted for the model validation. For the analysis of soil moisture, the observation period ranging from 4/4/2009 to 5/7/2009 was used for the calibration, while the period from 2/4/2010 to 3/27/2010 was adopted for the validation. The parameters used in calibration for streamflow and soil moisture with the SWAT model in the BERJ are presented in Table 2.

Table 2. Parameters used in calibration for streamflow and soil moisture with SWAT model in the Jatobá Basin, Pesqueira-PE.

\begin{tabular}{ccclc}
\hline $\mathrm{N}^{\mathrm{o}}$ & $\begin{array}{c}\text { Ranking } \\
\text { (Fontes Júnior, 2016) }\end{array}$ & Parameter & Description & Calibrated value \\
\hline 1 & $3^{\circ}$ & CN2 & $\begin{array}{l}\text { Curve number, moisture } \\
\text { condition II } \\
\text { Base flow recession constant, } \\
\text { days } \\
\text { Depth of water in shallow } \\
\text { aquifer required for return } \\
\text { flow, mm }\end{array}$ & 73.7 \\
3 & $2^{\circ}$ & ALPHA_BF & 700 \\
\hline
\end{tabular}

For evaluating the model precision, observed and simulated hydrographs were used, as well as the coefficient of determination $\left(\mathrm{R}^{2}\right)$ and the Nash-Sutcliffe efficiency coefficient (NSE) (Brighenti et al., 2016; Melo Neto et al., 2014; Aragão et al., 2013). The $\mathrm{R}^{2}$ coefficient indicates the proportion of variance in the data observed captured by the model, while the NSE coefficient depends on the variance of the data simulated and the data observed. The results of the model are considered more representative as the values of $\mathrm{R}^{2}$ and NSE are closer to 1 . The NashSutcliffe coefficients (NSE) (Nash and Sutcliffe, 1970) in this work were classified according to Santhi et al. (2001); adapted by Bracmort et al. (2006), which considered the performance of 
the SWAT model, both in the calibration and in the validation, as being satisfactory when the NSE was above 0.5 .

\subsection{Land use change scenarios}

The basin in study (BERJ) exhibits degradation of the native vegetation, with the presence of secondary vegetation, and is susceptible to soil erosion (Santos et al., 2010), and efforts have been made to support reforestation programs, funded by the São Francisco Basin Committee (CBHSF, 2016). Thus, for this study, two scenarios were proposed: a scenario considered optimistic (reforestation) and another scenario considered pessimistic (agricultural expansion). For the first scenario, a reforestation with native vegetation (arborescent closed Caatinga) at high elevations of the BERJ was adopted (Figure 2B). Such scenario is a recommendation of the Management Plan of the São Francisco River Basin, for the semiarid region (CBHSF, 2016). The reforested area replaced $100 \%$ of the Gallery Forest present in the basin, as well as $8.33 \%$ of the arborescent open Caatinga and $46 \%$ of the total agricultural area. In total, arborescent open Caatinga vegetation was added to $21 \%$ of the entire area of reforestation. In the second scenario, the entire area considered reforested in the first scenario $(37.7 \%)$ was replaced by agriculture, simulating a possible agricultural expansion along the basin.

\section{RESULTS AND DISCUSSION}

\subsection{Sub-basins and Hydrologic Response Units (HRUs)}

Based on the results of the digital elevation model, 29 sub-basins were formed in the Experimental Basin. These hydrological areas were established considering drainage flow, boundaries of the river basin, the drainage basin and the sub-basins with their mouths.

The information generated in the maps of soil types, slope and land use provided the necessary data to delimit the Hydrologic Response Units (HRUs), with 104 HRUs being generated in this study. Veiga (2014) working in the Córrego Samambaia River Basin, in the Brazilian State of Goiânia, with an area of $31 \mathrm{~km}^{2}$ subdivided the basin into 15 sub-basins, creating 315 Hydrological Response Units. Castro (2013) when simulating the Experimental Basin of the High-Jardim River in the Federal District, with approximately $105 \mathrm{~km}^{2}$, established 6 sub-basins with 628 HRUs for the application of the SWAT model.

\subsection{Sensitivity analysis}

Figure 3 presents the results of the sensitivity analysis of the variable streamflow in the study area. The five parameters considered most sensitive for the BERJ were: CN2.mgt, ALPHA_BF.gw, CH_K2.rte, CH_N2.rte and SOL_K.sol. These parameters refer to surface runoff, base flow, hydraulic conductivity and water storage capacity in the soil surface. Lelis et al. (2012) observed that the parameter CN2.mgt was the most sensitive for two sub-basins in the São Bartolomeu Stream watershed in Southeastern Brazil. Topography, land use, basin delineation and rainfall period are considered the main factors related to the sensitivity of the parameters studied (Schmalz and Fohrer, 2009). The work carried out by Maneta et al. (2008) highlighted some of the parameters considered most-sensitive, such as hydraulic conductivity and the soil infiltration rate, which influence water movement from the surface to the subsurface layers. According to the authors, information regarding soil moisture and water levels in monitoring wells improved the calibration and reduced uncertainties related to the simulations.

\subsection{Calibration and validation analysis for streamflow and soil moisture}

The analysis of the simulated hydrograph, compared against the observed time series, allows the assessment of model performance and the temporal dynamics of the selected variable. Figure 4A presents the streamflow calibration hydrograph in 2009. The SWAT 
adjustments were adequate in the recession period, both in terms of calibration and validation, demonstrating that the model is well adjusted for low flow periods. The value of NSE for the streamflow calibration was 0.58 , with $\mathrm{R}^{2}$ being equal to 0.69 . The results were classified as "satisfactory" according to the NSE classification presented by Bracmort et al. (2006). The model adequately presented the peak runoff rate taken place on June 27, 2009, with precipitation of $10.9 \mathrm{~mm}$ and the previous five-day rainfall of $0.99 \mathrm{~mm}$, which generated an average observed surface runoff of $2.78 \mathrm{~m}^{3} / \mathrm{s}$ and an average simulated surface runoff of $2.02 \mathrm{~m}^{3} / \mathrm{s}$.

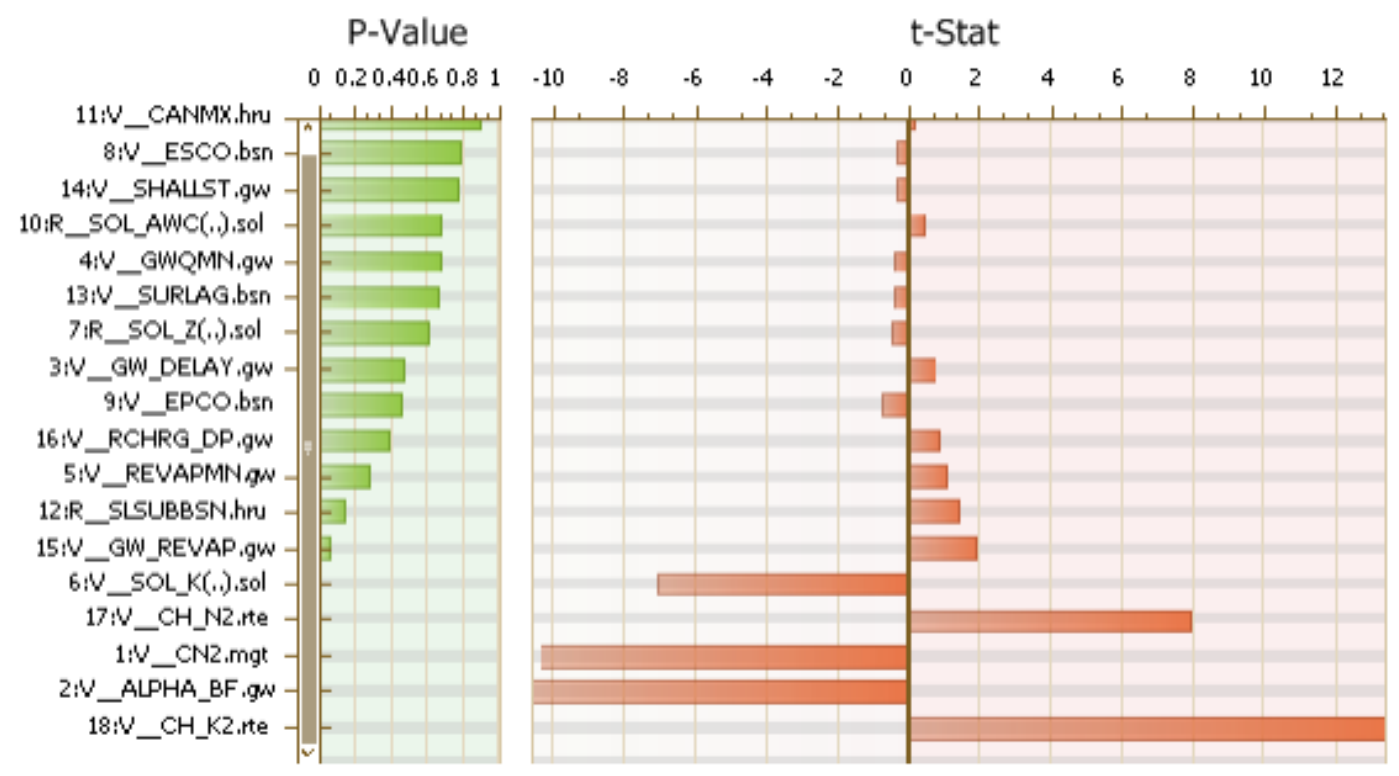

Figure 3. Sensitivity analysis performed by SWAT-CUP for streamflow daily observations.

Source: Fontes Júnior, 2016.
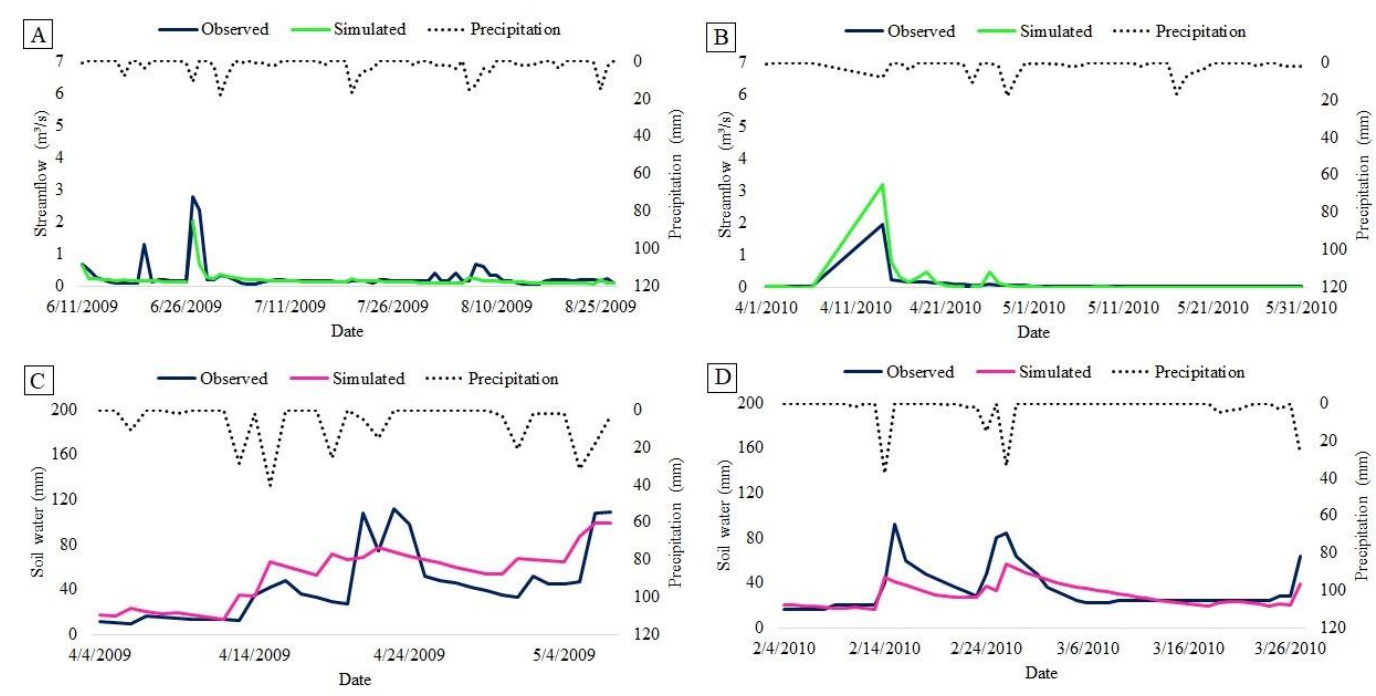

Figure 4. Calibration (A) and validation (B) of the streamflow and calibration (C) and validation (D) of the soil moisture in sub-basin located in soil moisture monitoring sites in Jatobá Stream Experimental Basin, Pesqueira-PE.

The results of the model validation for the year of 2010 are presented in Figure 4B. The model overestimated the mean value observed, with an average surface runoff of $0.79 \mathrm{~m}^{3} / \mathrm{s}$, with $3.21 \mathrm{~m}^{3} / \mathrm{s}$ for the simulated value, for a precipitation of $56.3 \mathrm{~mm}$. Nevertheless, the

\section{IPABH}


validation NSE coefficient was 0.42 . In average terms, the value observed for the streamflow in the validation period was $0.08 \mathrm{~m}^{3} / \mathrm{s}$, while the value simulated by the SWAT was very close to that observed, being equal to $0.12 \mathrm{~m}^{3} / \mathrm{s}$. Consequently, the $\mathrm{R}^{2}$ value was very good, being equal to 0.97 . The $\mathrm{R}^{2}$ for the validation period was higher than for the calibration, indicating no severe discrepancy between the simulated and observed hydrographs.

The NSE coefficients found comported with the ones obtained by Andrade et al. (2013), who applied the SWAT hydrological model in the Jaguara Stream watershed in the southern part of the Brazilian state of Minas Gerais, exhibiting NSE coefficients of 0.66 and 0.87 for calibration and validation, respectively. Studies carried out in the headwater watershed of the Mantiqueira Mountains, applying the SWAT model, produced a NSE coefficient for calibration of 0.81 and of 0.79 for validation (Pinto, 2011).

Viola et al. (2009) applied the hydrological model in the Aiuruoca River Basin, obtaining NSE coefficients of 0.87 and 0.92 for the calibration and validation phases, respectively. Satisfactory results were also found by Viola et al. (2012) when applying hydrological modeling in a sub-basin of the Araguaia River, in the Brazilian State of Tocantins, with NSE coefficients of 0.74 and 0.75 for the calibration and validation stages, respectively.

Dantas et al. (2015) simulated streamflow and estimated sediment movement in the Taperoá River Basin, using the SWAT model. The results showed that the model presented a satisfactory result for the calibration stage, though not in the validation phase. In the study, a reduction of surface runoff in the basin could be verified, as a consequence of an increase in temperature, alterations of vegetative cover and the insertion of small- and medium-scale reservoirs.

In most recent studies involving the SWAT model, different alternative variables have been adopted for the calibration and validation of the model. These data include evapotranspiration (Miranda, 2017; Bressiani et al., 2015; Maneta et al., 2008), soil moisture (Maneta et al., 2008), potentiometric levels (Fontes Júnior, 2016) and leaf-area index (Miranda, 2017). Soil moisture is considered a parameter of great importance, associated with the movement processes in the soil. The understanding of this variable contributes to adopting adequate agricultural and irrigation management processes, and vegetation parametrization.

Maneta et al. (2008) studied the application of a hydrological model in an experimental basin in a semiarid region of Spain. The study pointed out the importance of evapotranspiration and soil moisture in the simulation of small-scale perennial semiarid watersheds. According to the authors, the application of models in river basins inserted in a semiarid region is considered challenging given the characteristics of such a region, in which irregular rainfall or heavy rain during short periods of time may lead to a discontinuous and perennial streamflow, with consequent local saturated layers and non-saturated areas.

The summary of the statistical results of calibration and validation of the SWAT model with streamflow and soil moisture data are presented in Table 3. Figure 4C presents the soil moisture calibration hydrograph in 2009, and Figure 4D illustrates the validation hydrograph in 2010. The NSE coefficients in the soil moisture calibration stage were 0.53 , with $\mathrm{R}^{2}$ being equal to 0.63 . The validation NSE and $\mathrm{R}^{2}$ coefficients were lower $\left(\mathrm{NSE}=0.46\right.$ and $\mathrm{R}^{2}=0.55$ ) than the calibration coefficients, similar to the NSE coefficients estimated for streamflow. The results found are thus classified as "satisfactory" for the calibration stage, according to the NSE classification presented by Bracmort et al. (2006). Montenegro and Ragab (2010) carried out a comparison between the soil moisture data simulated by the model with the soil moisture measurements observed. The authors estimated a determination coefficient of 0.70 between the simulated values and the observed data. The values and general trends of soil moisture were properly simulated by the DiCaSM model. 
Table 3. Summary statistics of calibration and validation for streamflow and soil moisture in daily time step with SWAT model in the Jatobá Basin, Pesqueira-PE.

\begin{tabular}{lcc}
\hline Statistics & Streamflow & Soil moisture \\
\hline \multicolumn{3}{c}{ Calibration } \\
\hline $\mathrm{R}^{2}$ & 0.69 & 0.63 \\
$\mathrm{NS}$ & 0.58 & 0.53 \\
\hline \multicolumn{3}{c}{ Validation } \\
\hline $\mathrm{R}^{2}$ & 0.97 & 0.55 \\
$\mathrm{NS}$ & 0.42 & 0.46 \\
\hline
\end{tabular}

\subsection{Hydrological processes under land-use change scenarios}

Table 4 shows the results of the water balance for current-use, reforestation and agricultural-expansion scenarios. The results reveal the magnitude of the impact of land use changes on water resources. When we observe the results of the reforestation scenario in relation to the current-use scenario, it is verified that the increased native forest provided a decrease in surface runoff of about $51 \%$ in the BERJ, corresponding to $13.2 \mathrm{~mm}_{\text {year }}{ }^{-1}$. This decrease in surface runoff can be explained by the ability of forests to intercept precipitation, reducing the water loss through runoff. This higher plant density also allows, through interception, more water infiltrated into the soil, with increased percolation and aquiferrecharge processes. In the present study, the increase of water percolation to the shallow aquifer was approximately 11 times greater in the reforestation scenario. In Brazil and in the world, several studies have been developed with the objective of verifying the effects of the land-use changes on the surface runoff dynamics in watersheds (Aragão et al., 2013; Blainski et al., 2011; Rodrigues et al., 2015; Silva et al., 2015; 2018). Blainski et al. (2011) applied the SWAT model to the Araranguá River Basin to evaluate the influence of agricultural activities on the basin's water availability. They considered different scenarios: i) current use, with predominance of rhiziculture in agricultural areas; ii) replacement of agriculture by reforestation; and iii) removal of vegetative cover from agricultural areas. The authors verified that the average flow rate was higher in the bare soil scenario, and this increase was attributed to the reduction of water infiltration into the soil and the increase in surface runoff.

Table 4. Water balance components for current use, reforestation and agricultural expansion scenarios in the Jatobá Basin.

\begin{tabular}{lccc}
\hline Variables of water balance & Current land use & $\begin{array}{c}\text { Scenario 1 } \\
\text { Reforestation }\end{array}$ & $\begin{array}{c}\text { Scenario 2 } \\
\text { Agricultural expansion }\end{array}$ \\
\hline Precipitation & 654.3 & 654.3 & 654.3 \\
Surface runoff & 25.99 & 12.8 & 28.81 \\
Percolation & 42 & 59 & 42 \\
Soil water & 200.72 & 131.01 & 221.64 \\
Base flow & 56.34 & 63.09 & 56.19 \\
Potential evapotranspiration & 1763.90 & 1763.90 & 1763.90 \\
Actual Evapotranspiration & 588.2 & 592.10 & 587.50 \\
Total sediment loading & $21.02 \mathrm{t} / \mathrm{ha}$ & $6.74 \mathrm{t} / \mathrm{ha}$ & $28.10 \mathrm{t} / \mathrm{ha}$ \\
\hline
\end{tabular}

Rodrigues et al. (2015) used the SWAT to analyze the outflow in the Pará River Basin, in Minas Gerais, Brazil, and to evaluate the impact caused by changes in land use on the basin's water availability. They considered two scenarios: original vegetation and current use. 
According to the authors, there was an increase of about $10 \%$ in the flow due to changes in soil use, basically contemplating the suppression of the original vegetation for grassland implantation in $38 \%$ of the basin. It is a fact that the forests attenuate the direct runoff and might increase evapotranspiration.

Another point worth mentioning regards soil loss: the reforestation scenario provided a reduction of the total sediment load generated, compared to the current use scenario. This lower sediment rate can be explained by the superior quantity of native vegetation, which is able to intercept the rainfall, reducing the impact of the raindrops that fall directly to the soil, which would cause the particles to detach and move, as erosion. According to Silva et al. (2015), reclaimed forest areas decrease streamflow and sediment movement, intensifying the importance of the preservation of native vegetation areas. Silva et al. (2018) evaluated the erosion process with simulated rainfall in different cover crops (beans, corn, bare land and Caatinga) in the semiarid region of Paraiba. In the evaluation, the soil covers with Caatinga showed less erosion and surface runoff when compared with the other treatments. According to the authors, the shape of the vegetative cover, the leaf area and the stem structure are determining factors for canopy water storage, influencing soil conservation and the hydrological responses in the semiarid environment. Aragão et al. (2013) identified that native vegetation and regenerated areas make it possible to reduce rainfall impacts on the soil, avoiding degradation and surface runoff, decreasing the sediment loading around the basin. These results reinforce even more the importance of the preservation of the nascent areas of the BERJ, and in regions where water security is highly vulnerable, as is the case in many Brazilian semiarid basins.

In this study, the average value of evapotranspiration was higher for the reforestation scenario $(592.1 \mathrm{~mm})$ when compared to the current-use scenario $(588.2 \mathrm{~mm})$. This fact can be explained by the higher density of vegetative cover in the recomposition scenario. According to Tucci and Clarke (1997) and Bruijnzeel (1996), the greatest amount of solar radiation absorption and consequently, the greatest energy available for evapotranspiration comes from forests, and in this way the direct evaporation of intercepted water tends to be higher. In turn, the suppression of vegetative cover results in a decrease in evapotranspiration, since less radiation absorption occurs and less capacity to remove water from the soil and to intercept precipitation. This leads to a decrease in vertical water flow and an increase in horizontal flow (Viola, 2008).

When we observe the results of the agricultural-expansion scenario in relation to the current-use scenario, it is verified that the increase in agricultural land provided an increase in surface runoff of approximately $11 \%$ in the BERJ, corresponding to $28.8 \mathrm{~mm}_{\text {year }}{ }^{-1}$. On the other hand, there was a decrease in the percolation process for the shallow aquifer of approximately $32 \%$, being only $0.48 \mathrm{~mm}$. When observing the evapotranspiration, it is noticed that there was a decrease in the scenario of agricultural expansion compared to the current use of $0.12 \%$. These changes are in line with the same principles discussed earlier for the reforestation scenario. This is because these agricultural areas, in the current condition, are occupied by vegetation. It was verified that the increase of agricultural areas resulted in a greater surface runoff, a lower percolation of water in the soil and a lower evapotranspiration.

The amplitude and dispersion of data on simulated streamflow and soil moisture in scenarios of reforestation, agricultural expansion and current use in the Jatobá Basin are shown in Figure 5. From the obtained results by the SWAT model, it is possible to verify that between the scenarios, there was an increase of the average values of evapotranspiration in the reforestation scenario, due to the greater area of vegetative cover that provides greater evapotranspiration. Mean values and amplitudes of streamflow were increasing over the scenarios, being smaller in the condition of reforestation, then increasing in the current use, and 
finally, the greatest generation of streamflow occurred in the condition of agricultural expansion.
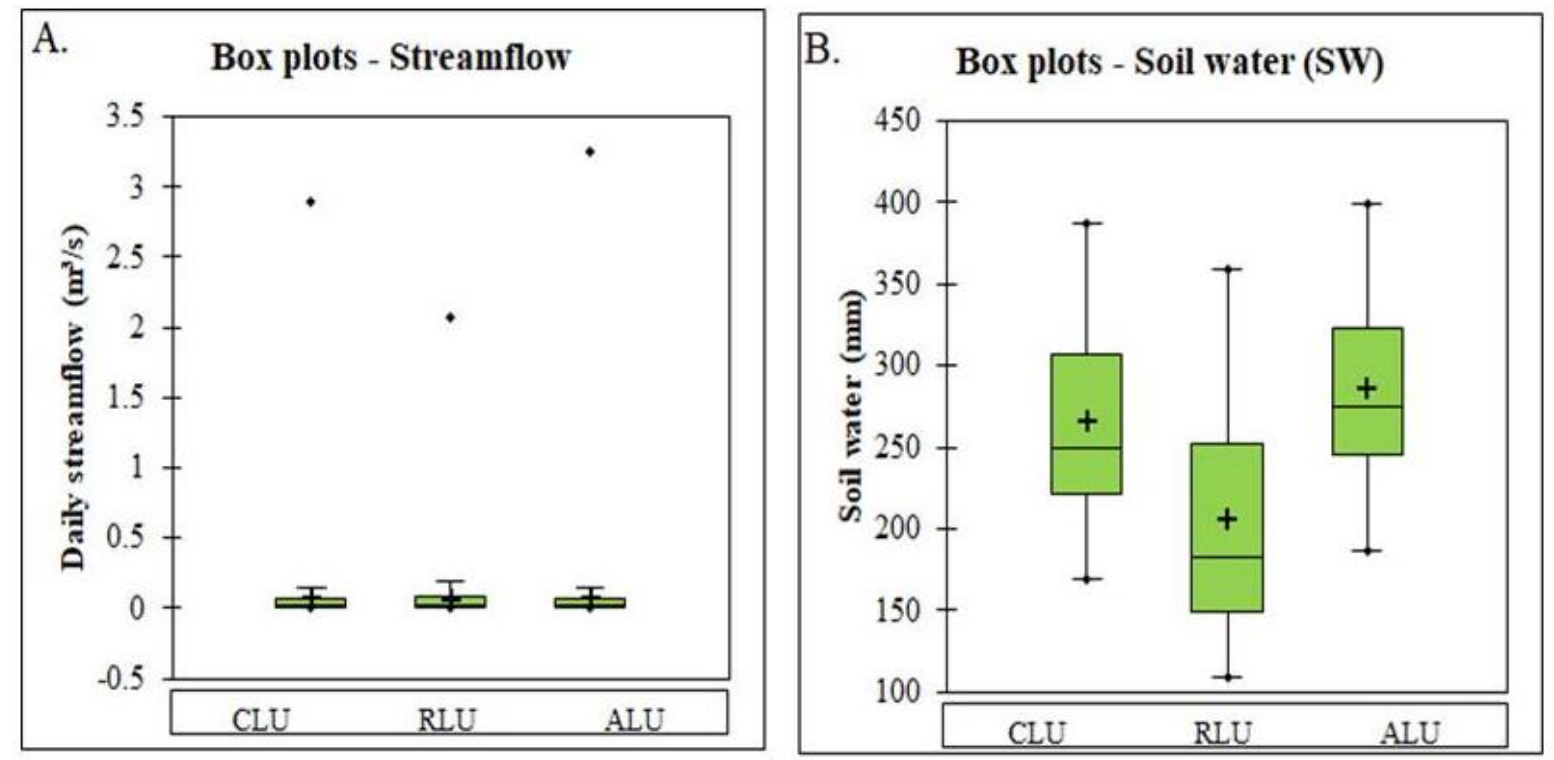

Figure 5. Box plots for streamflow and soil moisture in daily time step in the Jatobá Basin, PesqueiraPE.

In the Alto Ipanema Basin, Montenegro and Ragab (2010) verified that converting 7\% of Caatinga to agriculture area increased streamflow by 3\%. According to Munoz-Villers and Mcdonnell, 2013; and Yan et al., 2013, the change in land use is one of the main causes of surface runoff changes in a watershed, due to changes in precipitation interception, evapotranspiration and soil hydraulic conductivity. Within this context, knowledge of the effects of land use change on water dynamics in watersheds is of great importance in order to assist decision making within the scope of water resource management (Kuhnle et al., 1996).

Figure 6A presents the time series for soil moisture depths for the three scenarios analyzed, highlighting that a well-defined pattern of variation is similar for all series (Figure 6B). Figure 6C exhibits the time series for percolation $(\mathrm{mm})$ for the three scenarios and Figure 6D presents the scatter plot of the two modified scenarios as a function of the current land use. Differences of soil moistures between the current and reforested scenarios tends to increase for lower values of soil moisture. It can be verified that the impact of reforestation (decreasing soil moisture) is higher than that produced by the conversion of the current scenario to agriculture, the latter producing slightly higher soil moisture depths. When verifying percolation from the vadose zone, reforestation tends to increase such flux, as shown both in the time series (Figures 6A and 6B) and in the scatter plot in Figure 6D. 

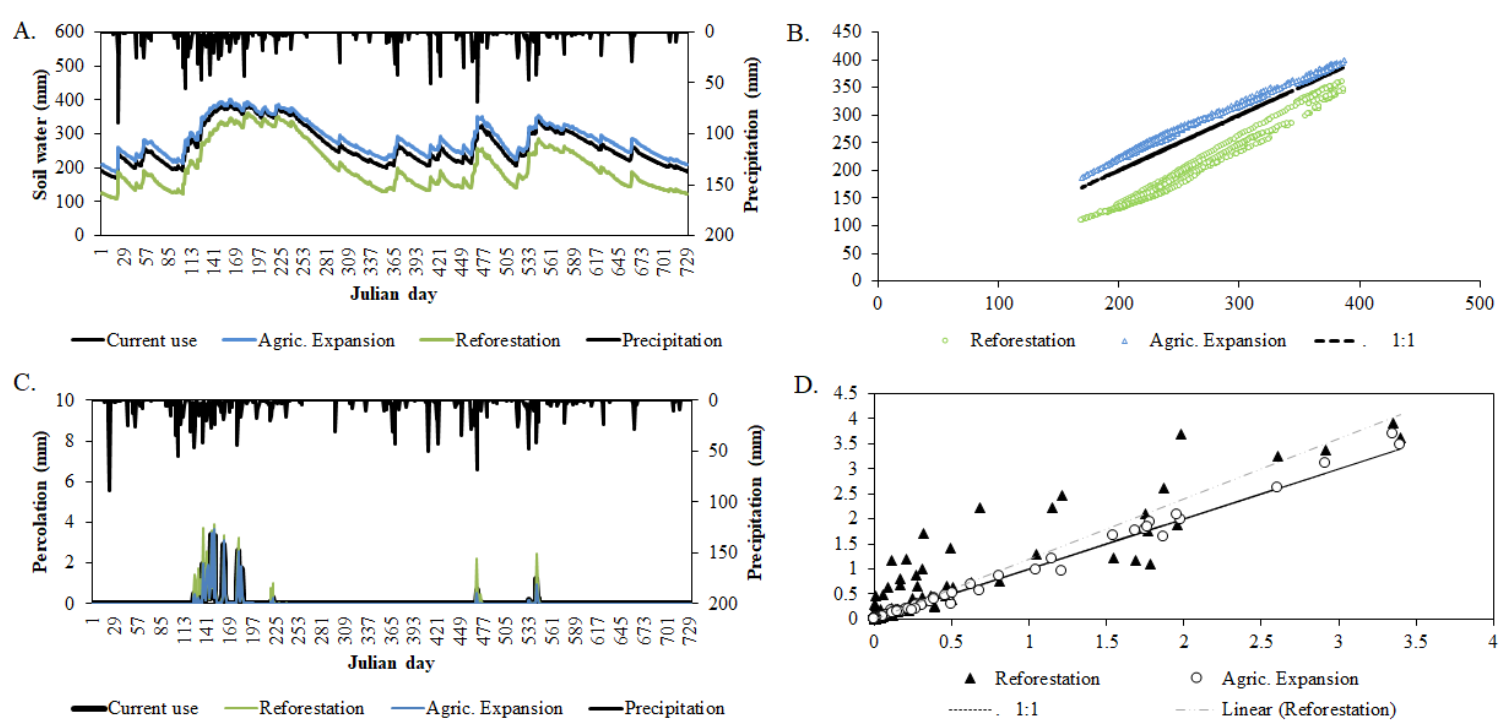

Figure 6. (A) Time series for soil moisture for the three scenarios analyzed; (B) pattern of variation for the series; (C) time series for percolation $(\mathrm{mm})$ for the three scenarios; and (D) scatter plot of the two modified scenario as function of the current land use.

\section{CONCLUSIONS}

The parameters most sensitive to the SWAT model were related to surface runoff, baseflow and hydraulic conductivity. The alternative process of calibration and validation in terms of both flow and soil moisture presented satisfactory results according to the NSE coefficients obtained, contributing to a more realistic simulation. Scenarios of regeneration of the vegetation cover of $21 \%$ of the area of arborescent Caatinga on hilltops led to significant changes on soil moisture and streamflow, thus contributing to the recovery of headwaters, increasing the base flow and the resilience to scenarios of water scarcity. On the other hand, the scenario of agricultural expansion caused an increase in surface runoff and, consequently, a decrease in the soil water storage.

\section{ACKNOWLEDGEMENTS}

This work was supported in part by the Foundation for Science and Technology of Pernambuco State (FACEPE) (Grants APQ 0300-5.03/17, APQ 0913-5.03/15 and Doctoral scholarship), the National Council for Scientific and Technological Development (CNPq) (Grants no. 446254/2015 (Super Project)) and the Brazilian Innovation Agency (FINEP) (Grant REHIDRO no. 1830/ 2010). This study was also financed in part by the Coordination for the Improvement of Higher Education and Personnel (CAPES) - Finance Code 001 (PVE024/2013 project (Grant no. 23038007733/2013-76). We are also grateful for all important comments from the anonymous reviewers, which contributed to a significant upgrade of the manuscript.

\section{REFERENCES}

ABBASPOUR, K. C.; ROUHOLAHNEJAD, E.; VAGHEFI, S.; SRINIVASAN, R.; YANG, H.; KLOVE, B. A continental-scale hydrology and water quality model for Europe: Calibration and uncertainty of a high-resolution large-scale SWAT model. Journal of Hydrology, v. 524, p. 733-752, 2015. https://doi.org/10.1016/j.jhydrol.2015.03.027 
ABBASPOUR, K. C.; YANG, J.; MAXIMOV, I.; SIBER, R.; BOGNER, K.; MIELEITNER, $\mathrm{J}$. et al. Modelling hydrology and water quality in the pre-alpine/alpine Thur watershed using SWAT. Journal of Hydrology, v. 333, p. 413-430, 2007. https://doi.org/10.1016/j.jhydrol.2006.09.014

ANDRADE, M. A.; MELLO, C. R.; BESKOW, S. Simulação hidrológica em uma bacia hidrográfica representativa dos latossolos na região Alto Rio Grande, MG. Revista Brasileira de Engenharia Agrícola e Ambiental, v. 17, n. 1, p. 69-76, 2013. http://dx.doi.org/10.1590/S1415-43662013000100010

ARAGÃO, R.; CRUZ, M. A. S.; AMORIM, J. R. A.; MENDONÇA, L. C.; FIGUEIREDO, E. E.; SRINIVASAN, V. S. Análise de sensibilidade dos parâmetros do modelo SWAT e simulação dos processos hidrossedimentológicos em uma bacia no agreste nordestino. Revista Brasileira de Ciência do Solo, v. 37, p. 1091-1102, 2013. http://dx.doi.org/10.1590/S0100-06832013000400026

ARNOLD, J. G.; KINITY, J. R.; SRINIVASAN, R.; WILLIAMS, J. R.; HANEY, E. B.; NEITSCH, S. L. Input/Output Documentation Version 2012. Temple: Black and Research Center: Texas Water Resources Institute, 2012.

BALES, R. C. Hydrology, floods and droughts - Overview. Reference Module in Earth Systems and Environmental Sciences. In: NORTH, G. R.; PYLE, J.; ZHANG, F. (Eds.). Encyclopedia of Atmospheric Sciences. $2^{\text {nd }}$. Cambridge: Academic Press, 2015. p. 180184.

BLAINSKI, E.; SILVEIRA, F. A.; CONCEIÇÃO, G.; GARBOSSA, L. H. P.; VIANNA, L. F. Simulação de cenários de uso do solo na bacia hidrográfica do rio Araranguá utilizando a técnica da modelagem hidrológica. Agropecuária Catarinense, v. 24, n. 1, p. 65-70, 2011.

BLAINSKI, E.; PORRAS, E. A. A.; GARBOSSA, L. H. P.; PINHEIRO, A. Simulation of land use scenarios in the Camboriú River Basin using the SWAT model. Revista Brasileira de Recursos Hídricos, v. 22 e. 33, 2017. http://dx.doi.org/10.1590/23180331.011716110

BRACMORT, K. S.; ARABI, M.; FRANKENBERGER, J. R.; ENGEL, B. A.; ARNOLD, J. G. Modeling long-term water quality impact of structural BMPS. American Society of Agricultural and Biological Engineers, v. 49, n. 2, p. 367-384, 2006.

BRESSIANI, D. A.; GASSMAN, P. W.; FERNANDES, J. G.; GARBOSSA, L.; SRINIVASAN, R.; BONUMA, N. B. et al. A review of Soil and Water Assessment Tool (SWAT) applications in Brazil: challenges and prospects. International Journal of Agricultural and Biological Engineering, v. 8, n. 3 p. 1-27, 2015. https://doi.org/doi./0.3965/j.ijabe.20150803.1765

BRIGHENTI, T. M.; BONUMÁ, N. B.; CHAFFE, P. L. B. Calibração hierárquica do modelo Swat em uma bacia hidrográfica Catarinense. Revista Brasileira de Recursos Hídricos, v. 21, n. 1, p. 53-64, 2016. http://dx.doi.org/10.21168/rbrh.v21n1.p53-64

BRITTO, F. B.; MENEZES NETO, E. L.; NETTO, A. O. A.; REGO, N. A. C. Sustentabilidade hídrica da Sub-bacia do Rio Sangradouro, Sergipe. Revista Brasileira de Geografia Física, v. 7, n. 1, p. 155-164, 2014. 
BRUIJNZEEL, L. A. Predicting the hydrological impacts of land cover transformation in the humid tropics: the need for integrated research. In: GASH, J. H. C.; NOBRE, C. A.; ROBERTS, J. M.; VICTORIA, R. L. Amazonian deforestation and climate. Chichester: J Wiley, 1996. p. 15-55.

CASTRO, K. B. Avaliação do modelo SWAT na simulação da vazão em bacia agrícola do cerrado intensamente monitorada. 2013. $122 \mathrm{f}$. Dissertation (Master in Geoprocessing and Environmental Analysis) - Institute of Applied Geosciences, University of Brasília, Brasília, 2013.

COMITÊ DA BACIA HIDROGRÁFICA DO RIO SÃO FRANCISCO - CBHSF. Plano de Recursos Hídricos da Bacia Hidrográfica do Rio São Francisco, PRH-SF 2016-2025. Lisboa: Nemus, 2016. 74p.

DANTAS, J. C.; SILVA, M. A.; SILVA, R. M.; VIANNA, P. C. G. Simulação vazão-erosão usando o modelo SWAT para uma grande bacia da região semiárida da Paraíba. Geociências, v. 34, n. 4, p. 816-827, 2015.

EMPRESA BRASILEIRA DE PESQUISA AGROPECUÁRIA - EMBRAPA. Levantamento de reconhecimento de baixa e média intensidade dos solos do estado de Pernambuco. Recife, 2000.

FINGER, D.; VIS, M.; HUSS, M.; SEIBERT, J. The value of multiple data set calibration versus model complexity for improving the performance of hydrological models in mountain catchments. Water Resources Research, v. 51, p. 1939-1958, 2015. https://doi.org/10.1002/2014WR015712

FONTES JÚNIOR, R. V. P. Experimentação e modelagem hidrológica aplicada à bacia do Alto Ipanema - PE. 2016. 160f. Thesis (PhD in Agricultural Engineering) - Federal Rural University of Pernambuco, Recife, 2016.

GALHARTE, C. A.; VILLELA, J. M.; CRESTANA, S. Estimativa da produção de sedimentos em função da mudança de uso e cobertura do solo. Revista Brasileira de Engenharia Agrícola e Ambiental, v. 18, n. 2, p. 194-201, 2014. http://dx.doi.org/10.1590/S141543662014000200010

ILSTEDT, U.; BARGUÉS TOBELLA, A.; BAZIÉ, H. R.; BAYALA, J.; VERBEETEN, E.; NYBERG, G. et al. Intermediate tree cover can maximize groundwater recharge in the seasonally dry tropics. Scientific Reports, v. 6, n. 21930, p. 1-12, 2016. http://dx.doi.org/10.1038/srep21930

KHOI, D. N.; THOM, V. T. Parameter uncertainty analysis for simulating streamflow in river catchment of Vietnam. Global ecology and conservation, v. 4, p. 538-548, 2015. https://doi.org/10.1016/j.gecco.2015.10.007

KUHNLE, R. A.; BINGER, R. L.; FOSTER, G. R.; GRISSINGER, E. H. Effect of land use changes on sediment transport. Water Resources Research, v. 32, n. 3, p. 189-3196, 1996. https://doi.org/10.1029/96WR02104

KUNDU, D.; VERVOOT, R. W.; van OGTROP, F. F. The value of remotely sensed surface soil moisture for model calibration using SWAT. Hydrological Processes, v. 31, p. 2764-2780, 2017. https://doi.org/10.1002/hyp.11219 
LELIS, T. A.; CALIJURI, M. L.; SANTIAGO, A. F.; LIMA, D. C.; ROCHA, E. O. Análise de Sensibilidade e Calibração do Modelo Swat Aplicado em Bacia Hidrográfica da Região Sudeste do Brasil. Revista Brasileira de Ciência do Solo, v. 36, p. 623-634, 2012. http://dx.doi.org/10.1590/S0100-06832012000200031

LI, S.; ZHUANG, Y.; ZHANG, L.; DU, Y.; LIU, H. Worldwide performance and trends in nonpoint source pollution modeling research from 1994 to 2013: A review based on bibliometrics. Journal of Soil and Water Conservation, v. 69, p. 121-126, 2014. https://doi.10.2489/jswc.69.4.121A

LIMA, J. E. F. W.; MONTENEGRO, S. M. G. L.; MONTENEGRO, A. A. A.; KOIDE, S. Comparative hydrology: relationships among physical characteristics, hydrological behavior, and results of the SWAT model in different regions of Brazil. Revista Brasileira de Geografia Física, v. 7, n. 6, p. 1187-1195, 2014.

MANETA, M.; SCHANABEL, S.; JETTEN, V. Continuous spatially distributed simulation of surface and subsurface hydrological processes in a small semi-arid catchment. Hydrological Processes, v. 22, p. 2196-2214, 2008. https://doi.org/10.1002/hyp.6817

MELO, R. O.; MONTENEGRO, A. A. A. Dinâmica temporal da umidade do solo em uma bacia hidrográfica no semiárido Pernambucano. Revista Brasileira de Recursos Hídricos, v. 20, n. 2, p. 430-441, 2015. https://doi.10.21168/rbrh.v20n2.p430-441

MELO NETO, J. O.; SILVA, A. M.; MELlO, C. R.; MÉLlO JÚNIOR, A. V. Simulação hidrológica escalar com o Modelo SWAT. Revista Brasileira de Recursos Hídricos, v. 19, n. 1, p. 177-188, 2014. https://doi.10.21168/rbrh.v19n1.p 177-188

MIRANDA, R. Q. Avaliação integrada da variação espacial e temporal do balanço hídrico na Caatinga utilizando o modelo hidrológico SWAT. 2017. $122 \mathrm{f}$. Thesis (PhD in Development and Environment) - Federal University of Pernambuco, Recife, 2017.

MONTENEGRO, A. A. A.; RAGAB, R. Hydrological response of a Brazilian semi-arid catchment to different land use and climate change scenarios: a modelling study. Hydrological Processes, v. 24, p. 2705-2723, 2010. https://doi.org/10.1002/hyp.7825

MONTENEGRO, A. A. A.; MONTENEGRO, S. M. G. L. Variabilidade espacial de classes de textura, salinidade e condutividade hidráulica de solos em planície aluvial. Revista Brasileira de Engenharia Agrícola e Ambiental, v. 10, n. 1, p. 30-37, 2006. http://dx.doi.org/10.1590/s1415-43662006000100005

MUNOZ-VILLERS, L. E.; MCDONNELL, J. J. Land use change effects on runoff generation in a humid tropical montane cloud forest region. Hydrological Earth System Science, v. 17, p. 3543-3560, 2013. https://doi.org/10.5194/hess-17-3543-2013

NASH, J. E.; SUTCLIFFE, J. V. River flow forecasting through conceptual models Part I - A discussion of principles. Journal of Hydrology, v. 10, p. 282-290, 1970. https://doi.org/10.1016/0022-1694(70)90255-6

NEITSCH, S. L.; ARNOLD, J. G.; KINIRY, J. R.; WILlIAMS, J. R. Soil and water assessment tool - Theoretical documentation version 2005. Temple: Black and Research Center: Texas Agricultural Experiment Station, 2005. Available: http://hdl.handle.net/1969.1/149194. Access: Apr. 2017. 
PINTO, D. B. F. Aplicação do modelo SWAT (Soil and Water Assessment Tool) na simulação hidrossedimentológica em bacia hidrográfica da Serra da Mantiqueira, MG. 2011. 225f. Thesis (PhD in Agricultural Engineering) - Federal Rural University of Lavras, Lavras, 2011.

RODRIGUES, E. L.; ELMIRO, M. A. T.; BRAGA, F. A.; JACOBI, C. M.; ROSSI, R. D. Impact of changes in land use in the flow of the Pará River Basin, MG. Revista Brasileira de Engenharia Agrícola e Ambiental, v. 19, n. 1, p. 70-76, 2015. http://dx.doi.org/10.1590/1807-1929/agriambi.v19n1p70-76

SANTHI, C.; ARNOLD, J. G.; WILLIAMS, J. R.; DUGAS, W. A.; SRINIVASAN, R.; HAUCK, L. M. Validation of the SWAT model on a large river basin with point and nonpoint sources. Journal of the American Water Resources Association, v. 37, n. 5, p. 1169-1188, 2001. https://doi.org/10.1111/j.1752-1688.2001.tb03630.x

SANTOS, J. Y. G. Análise espaço-temporal de processos hidrossedimentológicos na Bacia do Rio Tapacurá (Pernambuco, Brasil). 2015. 205f. Thesis (PhD in Civil Engineering of the Center of Technology and Geosciences), Federal University of Pernambuco, Recife, 2015.

SANTOS, T. E. M.; MONTENEGRO, A. A. A.; SILVA, D. D. Umidade do solo no semiárido pernambucano usando-se reflectometria no domínio do tempo (TDR). Revista Brasileira de Engenharia Agrícola e Ambiental, v. 15, n. 7, p. 670-679, 2011. http://dx.doi.org/10.1590/S1415-43662011000700004

SANTOS, T. E. M.; SILVA, D. D.; MONTENEGRO, A. A. A. Temporal variability of soil water content under different surface conditions in the semiarid region of the Pernambuco state. Revista Brasileira de Ciência do Solo, v. 34, n. 5, p. 1733-1741, 2010. http://dx.doi.org/10.1590/S0100-06832010000500025

SCHMALZ, B.; FOHRER, N. Comparing model sensitivities of different landscapes using the eco hydrological SWAT model. Advances in Geosciences, v. 21, p. 91-98, 2009. https://doi.org/10.5194/adgeo-21-91-2009

ŞEN, Z. Water Science Basic Information. Practical and Applied Hydrogeology, v. 1, p. 141, 2015. https://doi.org/10.1016/B978-0-12-800075-5.00001-7

SILVA, G. J. F. Estimativa de indicadores biofísicos para avaliação do processo de desertificação no município de São João do Cariri - PB. 2014. 127f. Dissertation (Master in Geography) - Federal University of Paraiba, João Pessoa, 2014.

SILVA, R. M. E.; MEDEIROS, I. C. Análise hidrossedimentológica em ambiente SIG usando o modelo SWAT. GeoFocus (Artículos), v. 14, p. 211-231, 2014.

SILVA, R. M.; SANTOS, C. A. G.; SANTOS, J. Y. G. Evaluation and modeling of runoff and sediment yield for different land covers under simulated rain in a semiarid region of Brazil. International Journal of Sediment Research, v. 33, n. 2, p. 117-125, 2018. https://doi.org/10.1016/j.ijsrc.2017.04.005

SILVA JUNIOR, V. P.; MONTENEGRO, A. A. A.; MELO, R. O. Temporal stability of soil moisture in an experimental watershed in the Pernambuco semiarid region. Revista Brasileira de Engenharia Agrícola e Ambiental, v. 20, n. 10, p. 880-885, 2016. http://dx.doi.org/10.1590/1807-1929/agriambi.v20n10p880-885 
SILVA JUNIOR, V. P.; MONTENEGRO, A. A. A.; SILVA, T. P.; GUERRA, S. M.; SANTOS, E. S. Produção de água e sedimentos em bacia representativa do semiárido pernambucano. Revista Brasileira de Engenharia Agrícola e Ambiental, v. 15, n. 10, p. 1073-1081, 2011.

SILVA, J. R. L.; MONTENEGRO, A. A. A.; MONTEIRO, A. L. N.; SILVA JUNIOR, V. P. Modelagem da dinâmica de umidade do solo em diferentes condições de cobertura no semiárido pernambucano. Revista Brasileira de Ciências Agrárias, v. 10, n. 2, p. 293 303, 2015. http://dx.doi.10.5039/agraria.v10i2a4219

TUCCI, C. E. M.; CLARKE, R. T. Impacto das mudanças de cobertura vegetal no escoamento: Revisão. Revista Brasileira de Recursos Hídricos, v. 2, p. 135-152, 1997. http://dx.doi.10.21168/rbrh.v2n1.p135-152

UNIYAL, B.; JHA, M. K.; VERMA, A. K. Parameter identification and uncertainty analysis for simulating streamflow in a River Basin of Eastern India. Hydrological Processes, v. 29, n.17 p. 3744-3766, 2015. https://doi.org/10.1002/hyp.10446

VEIGA, A. M. Calibração do modelo hidrossedimentológicos SWAT na bacia hidrográfica do córrego samambaia, Goiânia - GO. 2014. 132f. Dissertation (Master's degree in Environmental Engineering) - Federal University of Goiás, Goiânia, 2014.

VIOLA, M. R. Simulação hidrológica na região Alto Rio Grande a montante do reservatório de Camargos/CEMIG. 2008. 120f. Dissertation (Master in Water and Soil Engineering) - Federal University of Lavras, Lavras, 2008.

VIOLA, M. R.; MELlO, C. R.; ACERBI JUNIOR, F. W.; SILVA, A.M. Modelagem hidrológica na bacia hidrográfica do Rio Aiuruoca, MG. Revista Brasileira de Engenharia Agrícola e Ambiental, v. 13, n. 5, p. 581-590, 2009.

VIOLA, M. R.; MELLO, C. R.; GIONGO, M.; BESKOW, S.; SANTOS, A. F. Modelagem Hidrológica em uma Sub-bacia Hidrográfica do Baixo Rio Araguaia, TO. Journal of Biotechnology and Biodiversity, v. 3, n. 3, p. 38-47, 2012.

YAN, B.; FANG, N. F.; ZHANG, P. C.; SHI, Z. H. Impacts of land use change on watershed streamflow and sediment yield: an assessment using hydrologic modelling and partial least squares regression. Journal of Hydrology, v. 484, p. 26-37, 2013. https://doi.org/10.1016/j.jhydrol.2013.01.008 